\title{
Efek Teh Daun Kelor (Moringa Oleifera Tea) terhadap Kadar Leukosit Ibu Hamil
}

\author{
St. Hasriani ${ }^{*}$, Werna Nontji ${ }^{1}$, Veny Hadju², Suryani As'ad ${ }^{3}$, Andi Wardihan Singrang? \\ Burhanuddin Bahar ${ }^{4}$ \\ 1. Program Studi Kebidanan, Sekolah Pascasarjana, Universitas Hasanuddin Makassar, email: \\ sthasrianistkm@gmail,com*,werna_uh@yahoo.co.id \\ 2. Fakultas Kesehatan Masyarakat, Universitas Hasanuddin Makassar \\ 3. Fakultas Kedokteran, Universitas Hasanuddin Makassar
}

\begin{abstract}
Abstrak. Leukosit adalah system imun tubuh yang terlibat dalam pertahanan tubuh terhadap penyakit dan bahan asing. Jika terjadi peningkatan jumlah leukosit berisiko terjadi kelahiran prematur, ketuban pecah dini dan infeksi neonatus. Apabila terjadi penurunan sistem imun akan terjadi penurunan ketahanan tubuh terhadap penyakit terutama infeksi untuk memperbaiki sistem imun dipengaruhi beberapa faktor salah satunya zat gizi makro mikro. Daun kelor kaya kandungan nutrisi yang merupakan alternatif untuk menanggulangi terjadinya kekurangan zat gizi dan infeksi. Penelitian bertujuan menggambarkan efek the daun kelor (Moringa Oleifera Tea) terhadap kadar leukosit pada ibu hamil. Metode digunakan yaitu Quasi Experiment non randomized control group pretest-posttest design. Teknik pengambilan sampel dengan menggunakan teknik purposive sampling pada ibu dengan usia kehamilan trimester III ( $\geq 28$ minggu) di Puskesmas Pangkajene dan Puskesmas Lawawoi Kabupaten Sidenreng Rappang. Subjek dibagi menjadi dua kelompok yaitu kelompok intervensi 18 subjek dan kelompok kontrol 18 subjek. Hasil analisis rerata kadar leukosit pada kelompok teh daun

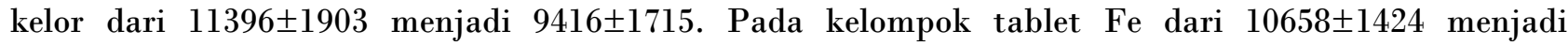
$10967 \pm 964$ dengan selisih 1979 dan 308 ( $p=0.002)$ dapat disempulakn bawha terdapat perbedaan rerata nilai kadar leukosit antara kelompok teh daun kelor dan kelompok tablet Fe, dimana teh daun kelor lebih efektif menurunkan kadar leukosit ibu hamil.
\end{abstract}

Kata kunci : Kadar Leukosit, Ibu Hamil, Teh Daun Kelor

\section{Effects of Moringa Oleifera Tea on Leukocyte Levels of Pregnant Women}

\begin{abstract}
Leukocytes are the immune system that is involved in defending the body against disease and foreign material. If there is an increase in the number of leukocytes, there is a risk of premature birth, premature rupture of membranes and neonatal infection. If the immune system declines, there will be a decrease in the body's resistance to diseases, especially infections and to improve the immune system there are several factors, one of which is the intake of micro-nutrients. Moringa leaves are rich in nutritional content which is an alternative to overcome the occurrence of nutrient deficiencies and infections. This research aims to describe the effect of Moringa Oleifera Tea on the levels of pregnant women leukocytes. The method used in this research is Quasi Experiment non randomized control group pretest-posttest design. Sampling was done by purposive sampling in third trimester of pregnant women ( $\geq 28$ weeks) at the Pangkajene and Lawawoi Health Center in Sidenreng Rappang Regency which were divided into two groups: an intervention group of 18 subjects and a control group of 18 subjects. The results of the average analysis of leukocyte levels in the

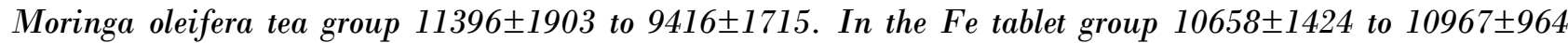
with the difference in 1979 and 308 ( $p=0.002)$ it can be concluded that there are differences in the average value of leukocyte levels between the Moringa oleifera tea group and the Fe tablet group, where Moringa oleifera tea is more effective in reducing leukocyte levels of pregnant Women
\end{abstract}

Keywords : Leukocyte Levels, Pregnant Women, Moringa Oleifera Tea

\section{Pendahuluan}

Leukosit merupakan sel darah putih yang terlibat dalam system kekebalan tubuh dalam membantu mempertahankan tubuh terhadap penyaki infeksi dan bahan asing. Nilai sebenarnya dari sel-sel darah putih adalah bahwa sebagian besar secara khusus diangkut ke daerah-daerah infeksi serius dan peradangan, sehingga cepat dan kuat dalam pertahanan terhadap agen infeksi (Samuel et al, 2015). 
Sistem imun ibu mengalami perubahan besar selama kehamilan, kemungkinan dipengaruhi oleh lingkungan hormon yang terus berubah. Perubahan ini sangat penting dalam mempertahankan kehamilan (Zhang et al., 2017). Leukosit bekerja sama dengan komplemen dan imunoglubulin dalam respon imun. Eosinofil, netrofil, basofil, dan eosinofil merupakan jenis leukosit bersifat fagosit yang menghancurkan dan menelan patogen dan sisa sel. Leukosit meningkat menunjukkan ada peradangan pada jaringan terhadap aktivasi pertahanan dan system imun tubuh.(Samuel et al., 2015).

Infeksi dapat terjadi karena system kekebalan tubuh diserang oleh bakteri maupun virus. Jika terjadin penurunan system imun maka terjadi penurunan ketahanan tubuh terhadap penyakit terutama infeksi. Untuk memperbaiki system imun sendiri dipengaruhi oleh beberapa faktor salah satunya adalah zat gizi makro dan mikro (Wang et al., 2017).

Daun kelor mengandung berbagai zat gizi mikro yang sangat dibutuhkan ibu hamil yaitu: thiamin, riboflavin, niacin, beta carotene, kalsium, zat besi, fosfor, magnesium, seng, vitamin $\mathrm{C}$, yang dapat menjadi alternative untuk menggantikan suplemen multiple mikronutrien dalam meningkatkan status gizi ibu hamil. Tumbuhan ini kaya akan protein, asam amino, mineral, vitamin, antioksidan dan anti-inflamasi. (Gopalakrishnan et al, 2016, Udikala et al, 2017, Koul \& Chase, 2015),

\section{Metode}

Desain penelitian adalah quasi experimental design deng Desain penelitian adalah quasi experimental non randomized control group pretest posttest design. Peneliti menganalisis dan membandingkan hasil intervensi berupa pembeian teh daun kelor (kelompok Intervensi) dengan Tablet zat besi (Fe) (kelompok kontrol). Teknik pengambilan sampel dengan menggunakan teknik purposive sampling pada ibu dengan usia kehamilan trimester III atau $\geq 28$ minggu di Puskesmas Pangkajene dan Puskesmas Lawawoi Kabupaten Sidenreng Rappang mulai September sampai November 2019, yang dibagi dalam dua kelompok (kelompok intevensi 18 subjek dan kelompok control 18 subjek) jadi jumlah subjek secara keseluruhan adalah sebanyak 36 subjek. Data dianalisis dengan SPSS versi 21.0, dengan uji-T Independen, paired T-Test dan Chi-Square dan dianggap signifikan secara statistik jika p-Value < 0.05.an rancangan non randomized control group pretest postest design. Peneliti menganalisis dan membandingkan hasil intervensi berupa pembeian teh daun kelor (kelompok Intervensi) dengan Tablet zat besi (Fe) (kelompok kontrol). Pengambilan sampel dilakukan dengan teknik purposive sampling pada ibu dengan usia kehamilan trimester III atau $\geq 28$ minggu yang melakukan kunjungan ANC di Puskesmas Pangkajene dan Puskesmas Lawawoi Kabupaten Sidenreng Rappang mulai September sampai November 2019, yang dibagi menjadi dua kelompok yaitu kelompok intervensi sebanyak 18 subjek dan kelompok kontrol sebanyak 18 subjek, jadi jumlah subjek secara keseluruhan adalah sebanyak 36 subjek. Data dianalisis dengan SPSS versi 21.0, dengan uji-T Independen, paired T-Test dan Chi-Square dan dianggap signifikan secara statistik jika $p$-Value $<0.05$.

\section{Hasil Penelitian}

Efek Daun Kelor Terhadap Kadar Leukosit Ibu Hamil

Tabel 1. Kadar Leukosit Ibu Hamil Sebelum dan Setelah Pemberian The Daun Kelor dan Tablet Zat Besi (Fe) pada Kelompok Intervensi Dan Kelompok Kontrol

\begin{tabular}{|c|c|c|c|c|c|c|}
\hline \multirow{2}{*}{ Variabel } & \multirow{2}{*}{ Kelompok } & Sebelum & Setelah & & \multirow{2}{*}{$\Delta$ Mean } & \multirow{2}{*}{$\mathbf{P}$} \\
\hline & & Mean \pm SD & Mean \pm SD & & & \\
\hline \multirow[t]{2}{*}{ Leukosit } & Intervensi & $11396 \pm 1903$ & $9416 \pm 1715$ & $0.001^{*}$ & 1979 & $0.002^{\wedge}$ \\
\hline & Kontrol & $10658 \pm 1424$ & $10967 \pm 964$ & $0.079^{*}$ & -308 & \\
\hline
\end{tabular}

Paired Sampels T-Test ${ }^{*}$, Independent Sampels T-Test ${ }^{\wedge}$ 
Tabel 1 menunjukan rerata nilai kadar leukosit pre test mean \pm SD pada kelompok intevensi $11396 \pm 1903$ dan nilai rerata post test $9416 \pm 1715$ dengan nilai ( $p$ value $=0.001)$. sedangkan kelompok kontrol rerata nilai berat badan pre test mean \pm SD $10658 \pm 1424$ dan rerata nilai post test $10967 \pm 964$ dengan nilai ( $p$-value $=0.079$ ), nilai selisih kelompok intervensi 1979 dan kelompok kontrol 308 dengan nilai ( $p$ value $=0.002$ ).

\section{Pembahasan}

Berdasarkan uji statistik pada tabel 1 menunjukkan rerata nilai kadar leukosit antara kelompok teh daun kelor memiliki perbedaan yang signifikan pada kelompok teh daun kelor dengan nilai ( $p$ value $=0.001)$ dan pada kelompok tablet zat besi (Fe) kelompok dengan nilai ( $p$ value $=0.079)$ selisih nilai rerata kelompok intervensi 1979 dan kelompok kontrol 308 dengan nilai ( $p$-value $=0.002)$. Berdasarkan nilai probabilitas, $p<0.05$. Hal ini menunjukkan bahwa ada efek pemberian teh daun kelor dan tablet zat besi $(\mathrm{Fe})$ terhadap kadar leukosit ibu hamil.

(Samuel et al., 2015) mengungkap bahwa daun kelor berguna untuk pasien anemia baik dalam dosis rendah dan relatif tinggi. Ada perbedaan yang signifikan dalam jumlah sel darah merah (eritrosit) dan sel darah putih (leukosit) dengan pemberian daun kelor menunjukkan bahwa tidak hanya baik sebagai suplemen makanan tetapi juga obat.

$$
\text { Penelitian (Prakasa, 2015) }
$$

menujukkan bahwa peningkatan leukosit dapat disebabkan peningkatan radikal bebas yang mengakibatkan aktivasi NF-kB berperan peningkatan leukosit. Selain itu penyakit infeksi dapat mengakibatkan stress oksidatif yang ditandai dengan meningkatnya radikal bebas dan reaksi inflamasi berupa peningkatan jumlah leukosit (Khuzaimah et al., 2015).

Saat stres sistem hormonal yang bekerja dalam tubuh menjadi kacau. Stres membuat hormon-horman bekerja menjadi tidak seimbang sehingga mengacaukan keselarasan fungsi tubuh. Dalam kondisi seperti ini, beban kerja tubuh menjadi semakin berat yang membuat sistem imun tubuh menurun dan menyebabkan peradangan. Saat terjadi peradangan tubuh akan melawan dengan mengeluarkan zat anti peradangan melalui reaksi oksidasi yang berguna namun menimbulkan dampak buruk yang berbahaya dibanding peradangan itu sendiri (Wang et al., 2017, Mansour et al, 2018).

Daun kelor mengandung berbagai insur zat gizi makro yang dibutukan ibu hamil yaitu: thiamin, riboflavin, niacin, beta-carotene, kalsium, zat besi, fosfor, magnesium,seng, vitamin $\mathrm{C}$, antioksidan dan anti-inflamasi. Pada daun kelor antioksidan dan anti-inflamasi berperan dalam menghambat aktivasi leukosit dan stress oksidatif yang disebabkan oleh radikal bebas (Khuzaimah et al., 2015, Sujatha \& Patel, 2017, Otoluwa et al., 2014).

\section{Simpulan}

Berdasarkan hasil penelitian dapat disimpulkan bahwa kadar leukosit terdapat perbedaan secara signifikan antara kelompok teh daun kelor sebelum dan setelah intervensi berpengaruh pada penurunan kadar leukosit dibanding dengan kelompok tablet zat besi ( $\mathrm{Fe})$, yang menunjukkan bahwa pemberian teh daun kelor lebih efektik dalam menurunkan kadar leukosit ibu hamil.

\section{Daftar Pustaka}

Gopalakrishnan, L., Doriya, K. and Kumar, D. S. (2016) 'Moringa oleifera: A review on nutritive importance and its medicinal application', Food Science and Human Wellness. Beijing Academy of Food Sciences., 5(2), pp. 49-56. doi: 10.1016/j.fshw.2016.04.001.

Khuzaimah, A. et al. (2015) 'Effect of Honey and Moringa Oleifera Leaf Extracts Supplementation for 
Preventing DNA Damage in Passive Smoking Pregnancy', International Journal of Sciences: Basic and Applied Research, 24(1), pp. 138145.

Koul, B. and Chase, N. (2015) 'Moringa oleifera Lam.: panacea to several maladies', Journal of Chemical and Pharmaceutical Research, 7(6), pp. 687-707. Available at: http://jocpr.com/vol7-iss62015/JCPR-2015-7-6-687-707.pdf.

Mansour, S. A. et al. (2018) 'The protective effect of moringa tea against cypermethrin-induced hepatorenal dysfunction, oxidative stress, and histopathological alterations in female rats', Asian Journal of Pharmaceutical and Clinical Research, 11(10), pp. 111-117. doi: 10.22159/ajpcr.2018.v11i10.24993.

Otoluwa, A. et al. (2014) 'Effect of Moringa Oleifera Leaf Extracts Supplementation in Preventing Maternal DNA Danage, International Journal of Scientific and Research Publications, 4(11), p. 3153. Available at: www.ijsrp.org.

Prakasa, A. B. (2015) 'Pengaruh Madu terhadap Jumlah Leukosit Total Akibat Paparan Asap Rokok', Majority, 4(7), pp. 73-76.

Samuel, S. A. et al. (2015) 'Effects of Moringa Oleifera leaf extract on red and white blood cells counts', International Journal of Current Medical and Pharmaceutical Research, 1(9), pp. 150-161.

Sujatha, B. K. and Patel, P. (2017) 'Moringa Oleifera - Nature 's Gold', Imperial Journal of Interdisciplinary research, 3(5), pp. 1175-1179.

Udikala, M. et al. (2017) 'Phytonutrient and Pharmacological Significance of Moringa oleifera', International Journal of Life-Sciences Scientific Research, 3(5), pp. 1387-1391. doi: 10.21276/ijlssr.2017.3.5.21.

Wang, R. et al. (2017) 'Earthquake experience at different trimesters during pregnancy is associated with leukocyte telomere length and longterm health in adulthood', Frontiers in Psychiatry, 8(OCT). doi: 10.3389/fpsyt.2017.00208.

Zhang, J. et al. (2017) 'Immunophenotyping and activation status of maternal peripheral blood leukocytes during pregnancy and labour, both term and preterm', Journal of Cellular and Molecular Medicine, 21(10), pp. 2386-2402. doi: $10.1111 /$ jemm.13160. 